Research Paper

\title{
SMAD7 polymorphisms and colorectal cancer risk: a meta- analysis of case-control studies
}

\author{
Yongsheng Huang ${ }^{1}$, Wenting $\mathbf{W u}^{2}$, Meng Nie ${ }^{1}$, Chuang $\mathrm{Li}^{1}$, Lin Wang ${ }^{1}$ \\ ${ }^{1}$ Institute of Basic Medical Sciences and School of Basic Medicine, Chinese Academy of Medical Sciences and Peking Union \\ Medical College, Beijing 100730, China \\ ${ }^{2}$ Department of Epidemiology, Richard M. Fairbanks School of Public Health, Melvin \& Bren Simon Cancer Center, Indiana \\ University, Indianapolis, IN 46202, USA \\ Correspondence to: Yongsheng Huang, email: yongsheng@ibms.pumc.edu.cn \\ Lin Wang, email: lin.wang@ibms.pumc.edu.cn \\ Keywords: SMAD7, colorectal cancer, polymorphism, meta-analysis \\ Received: April 15, $2016 \quad$ Accepted: September 14, $2016 \quad$ Published: September 27, 2016
}

\section{ABSTRACT}

Mothers against decapentaplegic homolog 7 (SMAD7) inhibits the transforming growth factor- $\beta$ (TGF- $\beta$ ) signaling pathway, which regulates carcinogenesis and cancer progression. A number of studies have reported that SMAD7 polymorphisms (rs4464148, rs4939827, and rs12953717) are associated with colorectal cancer (CRC) risk, but the results from these studies remain conflicting. To determine a more precise estimation of the relationship between SMAD7 and CRC, we undertook a large-scale meta-analysis of 63 studies, which included a total of 187,181 subjects $(86,585$ cases and 100,596 controls). The results of our meta-analysis revealed that the $\mathrm{C}$ allele of rs4464148 [CC vs. TT+TC, odds ratio $(O R)=1.23,95 \%$ confidence interval (CI): 1.14-1.33, $P<0.01$ ], the T allele of rs4939827 [TT vs. CC+TC, odds ratio $O R=1.15$, 95\%CI:1.07-1.22, $P<0.01$ ] and the T allele of rs12953717 [TT vs. CC+TC, OR $=1.22,95 \% C I: 1.16-1.29, P<0.01]$ were all associated with the increased CRC risk. Subgroup analysis according to ethnicity showed rs4464148 and rs12953717 were associated with the risk of CRC in both Caucasians and Asians, whereas rs4939827 was a risk polymorphism for CRC specifically in Caucasians. In summary, this largescale meta-analysis indicated that SMAD7 polymorphisms (rs4464148, rs4939827, and rs12953717) correlate with CRC.

\section{INTRODUCTION}

Cancer is caused by the dysfunction of intricate signaling pathways, leading to abnormal growth, metastasis, and many other events [1]. The transforming growth factor $\beta$ (TGF- $\beta$ ) signaling pathway is one of major tumor-regulatory pathways, exerting critical tumorsuppressive functions in the early stages of tumorigenesis $[2,3]$. When TGF- $\beta$ signaling is activated, downstream SMAD2 and SMAD3 proteins are phosphorylated, forming a complex with SMAD4 and then translocating to the nucleus to turn on and off the transcription of a wide range of target genes $[4,5]$. SMAD7 inhibits TGF- $\beta$ signaling by preventing the formation of the SMAD2/ SMAD4 complex [6]. It also interacts with activated TGF- $\beta$ type I receptor and blocks the phosphorylation and activation of SMAD2 [6].
SMAD7 has also been reported to affect tumorigenesis via several other mechanisms. First, in FET-1 colon cancer cells, SMAD7 induces the expression of $\mathrm{I} \kappa \mathrm{B}$, thereby repressing $\mathrm{NF}-\kappa \mathrm{B}$ activity [7]. Secondly, SMAD7 up-regulates MYC expression and WNT signaling via interactions with $\beta$-catenin in breast cancer [8] and hepatocellular carcinoma [9]. In addition, SMAD7 inhibits ERK1/2, JNK1/2, and p38 MAPKs under some circumstances related with tumorigenesis, such as erythroid differentiation [10] and chondrocyte differentiation [11].

In 2007, Broderick and co-workers [12] conducted a genome-wide association study and identified three polymorphic variants in intron 3 of SMAD7 (rs4464148, rs4939827, and rs12953717). Furthermore, they found these SMAD7 polymorphisms were associated with $\mathrm{CRC}$ adenomas and carcinomas [12]. In a number of 
other studies these SMAD7 polymorphisms have been associated with the risk of developing multiple cancers, including CRC [12-14], renal [15], and liver cancer [16]. However, other case-control studies have reported that these polymorphisms are not associated with cancer risk, in CRC [17-19], breast cancer [20], and lymphocytic leukemia [21]. These inconsistencies may be partially due to the relatively small sample sizes in each of these studies. Therefore, we performed a large-scale metaanalysis of all eligible published studies to derive a more precise quantitative assessment of the association between SMAD7 polymorphisms and CRC risk.

\section{RESULTS}

\section{Study selection and characteristics}

Figure 1 is a flowchart explaining the study selection process. A total of 62 articles were initially retrieved from PubMed, Web of Science, EBSCO, and Embase electronic databases (last updated in June, 2016). Based on the search criteria, we excluded 33 ineligible records after carefully reviewing the full text and data, leaving 29 articles published between 2007 and 2016 for our quantitative meta-analysis.

The characteristics of SMAD7 polymorphisms (rs4464148, rs4939827, and rs12953717) in selected studies are shown in Table 1. There were 64 eligible studies from 29 articles analyzing the relationship of SMAD7 polymorphisms and CRC risk. Among these studies, one was conducted on rs12953717, with a relatively small sample size (308 subjects) [22], which seems to have affected the results dramatically. Therefore, this study was excluded from analysis. Finally, 63 studies (published from 2007-2016) including 187,181 subjects $(86,585$ cases and 100,596 controls) were used to estimate the risk of developing CRC with SMAD7 polymorphisms. Each subpopulation in the literature was treated as a separate study in our meta-analysis. Populations were divided into ethnic categories. The Newcastle-Ottawa Scale (NOS) was used for quality assessment [23] and all of the studies achieved moderately high quality scores above 6 (Table 1). Among the included studies, 12 were conducted on rs4464148 (18,303 cases and 16,964 controls), 37 on rs4939827 (48,751 cases and 61,529 controls), and 14 on rs12953717 (19,531 cases and 22,103 controls).

\section{Quantitative data synthesis}

\section{SMAD7 rs4464148 polymorphism}

For each study, we investigated the association between the SMAD7 rs4464148 polymorphism and CRC risk, assuming different inheritance models. When all eligible studies were pooled into the meta-analysis, significant associations were found for the recessive genetic model (Table 2): CC vs. TC+TT (OR $=1.23 ; 95 \%$
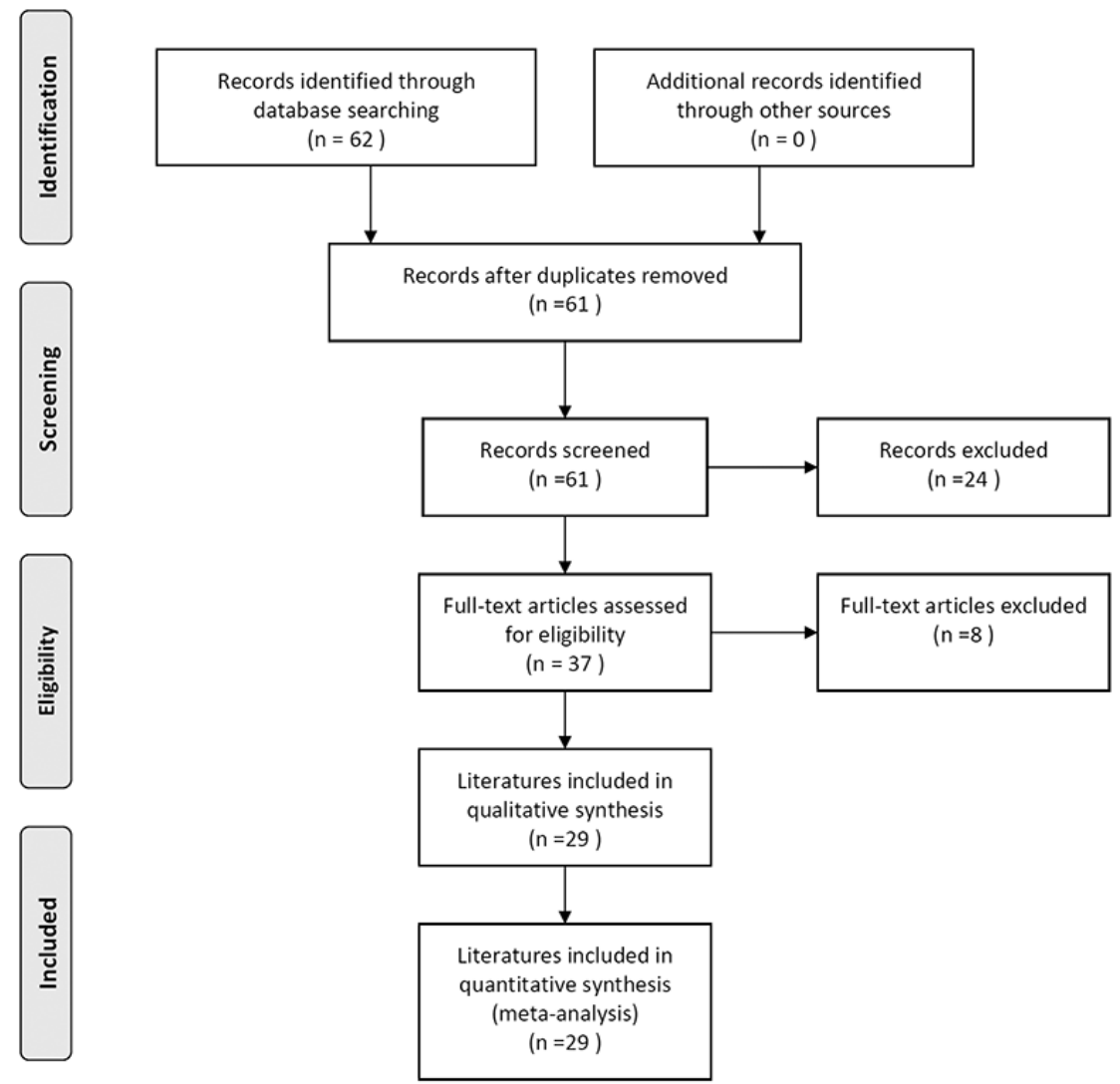

Figure 1: Flowchart of the literature selection process. 
Table 1: Main characteristics of all case-control studies included in the meta-analysis

\begin{tabular}{|c|c|c|c|c|c|c|c|c|c|c|c|c|c|c|}
\hline \multirow{2}{*}{$\begin{array}{l}\text { SNP } \\
\text { rs4464148 }\end{array}$} & \multirow[t]{2}{*}{ Author } & \multirow[t]{2}{*}{ Year } & \multirow[t]{2}{*}{ Ethnicity } & \multirow{2}{*}{$\begin{array}{c}\text { Cancer } \\
\text { type }\end{array}$} & \multicolumn{3}{|c|}{ Case } & \multicolumn{3}{|c|}{ Control } & \multirow{2}{*}{$\begin{array}{c}\text { HWE } \\
\text { (Control } \\
P \text { value) }\end{array}$} & \multirow{2}{*}{$\begin{array}{l}\text { Study } \\
\text { design }\end{array}$} & \multirow{2}{*}{$\begin{array}{c}\text { Genotyping } \\
\text { method }\end{array}$} & \multirow{2}{*}{$\begin{array}{c}\text { Quality } \\
\text { assessment }\end{array}$} \\
\hline & & & & & TT & TC & $\mathrm{CC}$ & TT & TC & $\mathrm{CC}$ & & & & \\
\hline & $\begin{array}{c}\text { Broderick et al. [12] } \\
\text {-A group }\end{array}$ & 2007 & Caucasian & Colon & 389 & 425 & 116 & 486 & 394 & 80 & 0.991 & GWAS & Illumina & 8 \\
\hline & -B group & 2007 & Caucasian & Colon & 2017 & 1952 & 472 & 1886 & 1617 & 346 & 0.982 & Replication & Allele-PCR & 8 \\
\hline & $-\mathrm{C}$ group & 2007 & Caucasian & Colon & 922 & 845 & 193 & 827 & 696 & 146 & 0.980 & Replication & Allele-PCR & 8 \\
\hline & -D group & 2007 & Caucasian & Colon & 422 & 408 & 99 & 171 & 137 & 27 & 0.952 & Replication & Allele-PCR & 8 \\
\hline & Thompson et al. [28] & 2009 & Caucasian & Colon & 269 & 231 & 61 & 342 & 324 & 53 & 0.045 & Replication & TaqMan & 8 \\
\hline & Curtin et al. [43] & 2009 & Caucasian & Colon & 503 & 472 & 95 & 535 & 423 & 89 & 0.678 & Replication & SNPlex & 8 \\
\hline & Pittman et al. [44] & 2009 & Caucasian & Colon & 1161 & 1107 & 264 & 1095 & 1277 & 235 & 0.996 & Replication & Allele-PCR & 8 \\
\hline & Ho et al. [35] & 2011 & Asian & Colon & 739 & 146 & 7 & 770 & 116 & 4 & 0.869 & Replication & Sequenom & 7 \\
\hline & Zhang et al. [38] & 2014 & Asian & Colon & 1 & 52 & 675 & 14 & 305 & 2957 & 0.999 & Replication & TaqMan & 8 \\
\hline & Kurlapska et al. [17] & 2014 & Caucasian & Colon & 1214 & 1228 & 400 & 84 & 96 & 33 & 0.523 & Replication & Sequenom & 7 \\
\hline & Damavand et al. [29] & 2015 & Caucasian & Colon & 138 & 78 & 37 & 113 & 101 & 20 & 0.700 & Replication & Taqman & 7 \\
\hline & $\begin{array}{c}\text { Serrano-Fernandez } \\
\text { et al. }[45]\end{array}$ & 2015 & Caucasian & Colon & 507 & 517 & 141 & 561 & 490 & 114 & 0.643 & Replication & Taqman & 8 \\
\hline \multirow[t]{34}{*}{ rs4939827 } & & & & & $\mathrm{CC}$ & TC & TT & $\mathrm{CC}$ & TC & TT & & & & \\
\hline & $\begin{array}{c}\text { Broderick et al. [12] } \\
\text {-A group }\end{array}$ & 2007 & Caucasian & Colon & 153 & 449 & 328 & 229 & 480 & 251 & 0.987 & GWAS & Illumina & 8 \\
\hline & -B group & 2007 & Caucasian & Colon & 852 & 2178 & 1392 & 845 & 1915 & 1084 & 0.989 & Replication & Allele-PCR & 8 \\
\hline & $-\mathrm{C}$ group & 2007 & Caucasian & Colon & 387 & 982 & 623 & 410 & 840 & 430 & 0.995 & Replication & Allele-PCR & 8 \\
\hline & -D group & 2007 & Caucasian & Colon & 194 & 477 & 292 & 76 & 171 & 96 & 0.923 & Replication & Allele-PCR & 8 \\
\hline & $\begin{array}{c}\text { Tenesa et al. [14] } \\
\text {-Scotland(GWAS) }\end{array}$ & 2008 & Caucasian & Colon & 538 & 1521 & 926 & 706 & 1508 & 845 & 0.506 & GWAS & Illumina & 8 \\
\hline & -Japan & 2008 & Asian & Colon & 233 & 1582 & 2576 & 131 & 1028 & 2019 & 0.992 & Replication & TaqMan & 8 \\
\hline & -Canada & 2008 & Caucasian & Colon & 225 & 593 & 355 & 284 & 576 & 322 & 0.402 & Replication & TaqMan & 8 \\
\hline & -England & 2008 & Caucasian & Colon & 418 & 1120 & 694 & 546 & 1126 & 578 & 0.959 & Replication & TaqMan & 8 \\
\hline & -Spain & 2008 & Caucasian & Colon & 62 & 156 & 131 & 57 & 143 & 95 & 0,808 & Replication & TaqMan & 8 \\
\hline & -Germany & 2008 & Caucasian & Colon & 420 & 1071 & 659 & 541 & 1057 & 530 & 0.765 & Replication & TaqMan- & 8 \\
\hline & -Germany & 2008 & Caucasian & Colon & 289 & 617 & 412 & 378 & 704 & 358 & 0.403 & Replication & TaqMan & 8 \\
\hline & -Scotland & 2008 & Caucasian & Colon & 156 & 420 & 254 & 189 & 446 & 288 & 0.497 & Replication & TaqMan & 8 \\
\hline & -Israel & 2008 & Caucasian & Colon & 267 & 638 & 447 & 312 & 627 & 397 & 0.035 & Replication & TaqMan & 8 \\
\hline & Curtin et al. [43] & 2009 & Caucasian & Colon & 221 & 520 & 324 & 229 & 538 & 274 & 0.251 & Replication & SNPlex & 8 \\
\hline & Thompson et al. [28] & 2009 & Caucasian & Colon & 125 & 275 & 154 & 146 & 378 & 185 & 0.064 & Replication & TaqMan & 8 \\
\hline & Pittman et al. [44] & 2009 & Caucasian & Colon & 785 & 1250 & 497 & 725 & 1300 & 582 & 0.987 & Replication & Allele-PCR & 8 \\
\hline & Slattery et al. [46] & 2010 & Caucasian & Colon & 360 & 773 & 457 & 492 & 992 & 503 & 0.947 & Replication & TaqMan & 8 \\
\hline & Xiong et al. [33] & 2010 & Asian & Colon & 1370 & 677 & 77 & 1442 & 570 & 74 & 0.061 & Replication & $\begin{array}{l}\text { T-ARMS- } \\
\text { PCR }\end{array}$ & 8 \\
\hline & von Hoslt et al. [47] & 2010 & Caucasian & Colon & 395 & 886 & 501 & 387 & 884 & 408 & 0.930 & Replication & deCode test & 8 \\
\hline & Kupfer et al. [48] & 2010 & African & Colon & 379 & 340 & 76 & 455 & 429 & 101 & 0.994 & Replication & Sequenom & 7 \\
\hline & & & Caucasian & Colon & 88 & 199 & 112 & 85 & 183 & 99 & 0.981 & Replication & Sequenom & 7 \\
\hline & Mates et al. [49] & 2010 & Caucasian & Colon & 28 & 37 & 27 & 15 & 57 & 23 & 0.061 & Replication & Centaurus & 6 \\
\hline & Mates et al. [50] & 2011 & Caucasian & Colon & 42 & 69 & 42 & 32 & 106 & 43 & 0.225 & Replication & Centaurus & 7 \\
\hline & Cui et al. [34] & 2011 & Asian & Colon & 1628 & 1007 & 155 & 2247 & 1190 & 147 & 0.501 & Replication & Illumina & 8 \\
\hline & Li et al. [22] & 2011 & Asian & Colon & 73 & 53 & 12 & 81 & 73 & 14 & 0.665 & Replication & Sequenom & 7 \\
\hline & Ho et al. [35] & 2011 & Asian & Colon & 343 & 420 & 129 & 376 & 405 & 109 & 0.997 & Replication & Sequenom & 7 \\
\hline & Song et al. [36] & 2012 & Asian & Colon & 399 & 232 & 10 & 732 & 272 & 33 & 0.214 & Replication & TaqMan & 6 \\
\hline & Lubbe et al. [51] & 2012 & Caucasian & Colon & 444 & 969 & 624 & 1394 & 3021 & 1636 & 0.993 & Replication & Allele-PCR & 7 \\
\hline & $\begin{array}{c}\text { Garcia-Albeniz et } \\
\text { al. [52] }\end{array}$ & 2012 & Caucasian & Colon & 90 & 233 & 118 & 538 & 1120 & 600 & 0.731 & Replication & TaqMan & 8 \\
\hline & Phipps et al. [53] & 2012 & Caucasian & Colon & 657 & 1526 & 884 & 574 & 1597 & 1112 & 0.988 & Replication & TaqMan & 7 \\
\hline & Kirac et al. [54] & 2013 & Caucasian & Colon & 63 & 143 & 96 & 172 & 291 & 131 & 0.705 & Replication & Illumina & 8 \\
\hline & Yang et al. [37] & 2014 & Asian & Colon & 342 & 298 & 65 & 891 & 752 & 159 & 0.985 & Replication & Allele-PCR & 7 \\
\hline & Kurlapska et al. [17] & 2014 & Caucasian & Colon & 54 & 93 & 65 & 716 & 1394 & 730 & 0.330 & Replication & Sequenom & 7 \\
\hline
\end{tabular}

(Continued) 


\begin{tabular}{|c|c|c|c|c|c|c|c|c|c|c|c|c|c|c|}
\hline \multirow[t]{5}{*}{ SNP } & \multirow{2}{*}{$\begin{array}{c}\text { Author } \\
\text { Zhang et al. [38] }\end{array}$} & \multirow{2}{*}{$\begin{array}{l}\text { Year } \\
2014\end{array}$} & \multirow{2}{*}{$\begin{array}{c}\text { Ethnicity } \\
\text { Asian }\end{array}$} & \multirow{2}{*}{$\begin{array}{c}\begin{array}{c}\text { Cancer } \\
\text { type }\end{array} \\
\text { Colon }\end{array}$} & \multicolumn{3}{|c|}{ Case } & \multicolumn{3}{|c|}{ Control } & \multirow{2}{*}{$\begin{array}{c}\begin{array}{c}\text { HWE } \\
\text { (Control } \\
P \text { value) }\end{array} \\
0.858\end{array}$} & \multirow{2}{*}{$\begin{array}{c}\begin{array}{c}\text { Study } \\
\text { design }\end{array} \\
\text { Replication }\end{array}$} & \multirow{2}{*}{$\begin{array}{c}\text { Genotyping } \\
\text { method }\end{array}$} & \multirow{2}{*}{$\begin{array}{c}\begin{array}{c}\text { Quality } \\
\text { assessment }\end{array} \\
7\end{array}$} \\
\hline & & & & & 400 & 277 & 51 & 1894 & 1170 & 212 & & & & \\
\hline & Hong et al. [19] & 2015 & Asian & Colon & 126 & 63 & 9 & 182 & 127 & 19 & 0.608 & Replication & Illumina & 7 \\
\hline & $\begin{array}{l}\text { Baert-Desurmont et } \\
\text { al. [55] }\end{array}$ & 2016 & Caucasian & Colon & 89 & 157 & 104 & 191 & 493 & 343 & 0.555 & Replication & SNaPshot & 8 \\
\hline & $\begin{array}{l}\text { Abd EI-Fattah et al. } \\
{[18]}\end{array}$ & 2016 & Caucasian & Colon & 20 & 35 & 22 & 11 & 15 & 10 & 0.319 & Replication & TaqMan & 7 \\
\hline \multirow[t]{15}{*}{ rs12953717 } & & & & & $\mathrm{CC}$ & TC & TT & $\mathrm{CC}$ & TC & TT & & & & \\
\hline & $\begin{array}{l}\text { Broderick et al. } \\
\text {-A group [12] }\end{array}$ & 2007 & Caucasian & Colon & 159 & 309 & 151 & 326 & 467 & 167 & 0.991 & GWAS & Illumina & 8 \\
\hline & -B group & 2007 & Caucasian & Colon & 1247 & 2204 & 973 & 1248 & 1898 & 722 & 0.994 & Replication & Allele-PCR & 8 \\
\hline & -C group & 2007 & Caucasian & Colon & 582 & 991 & 422 & 558 & 834 & 312 & 0.990 & Replication & Allele-PCR & 8 \\
\hline & -D group & 2007 & Caucasian & Colon & 277 & 468 & 198 & 106 & 168 & 67 & 0.976 & Replication & Allele-PCR & 8 \\
\hline & Middeldorp et al. [13] & 2009 & Caucasian & Colon & 301 & 493 & 201 & 482 & 643 & 215 & 0.982 & Replication & TaqMan & 7 \\
\hline & Curtin et al. [43] & 2009 & Caucasian & Colon & 314 & 530 & 226 & 332 & 521 & 188 & 0.509 & Replication & SNPlex & 8 \\
\hline & Thompson et al. [28] & 2009 & Mixed & Colon & 196 & 248 & 116 & 220 & 370 & 129 & 0.218 & Replication & TaqMan & 8 \\
\hline & Pittman et al. [56] & 2009 & Caucasian & Colon & 716 & 1261 & 555 & 859 & 1275 & 473 & 0.998 & Replication & Allele-PCR & 8 \\
\hline & Kupfer et al. [48] & 2010 & African & Colon & 401 & 327 & 67 & 525 & 388 & 72 & 0.979 & Replication & Sequenom & 7 \\
\hline & & 2010 & Caucasian & Colon & 197 & 121 & 81 & 119 & 180 & 68 & 0.996 & Replication & Sequenom & 7 \\
\hline & Slattery et al. [46] & 2010 & Caucasian & Colon & 503 & 754 & 332 & 676 & 928 & 327 & 0.779 & Replication & Illumina & 8 \\
\hline & Ho et al. [35] & 2011 & Asian & Colon & 276 & 343 & 97 & 304 & 345 & 65 & 0.557 & Replication & Sequenom & 7 \\
\hline & Scollen et al. [56] & 2011 & Mixed & Colon & 710 & 1031 & 425 & 730 & 1083 & 437 & 0.326 & Replication & TaqMan & 8 \\
\hline & Zhang et al. [38] & 2014 & Asian & Colon & 418 & 263 & 47 & 1947 & 1135 & 194 & 0.096 & Replication & TaqMan & 8 \\
\hline
\end{tabular}

SNP: single nucleotide polymorphisms: HWE: Hardy-Weinberg equilibrium.

Table 2: Meta-analysis of the association between $S M A D 7$ polymorphisms and colorectal cancer risk

\begin{tabular}{|c|c|c|c|c|c|c|c|c|}
\hline \multirow[t]{2}{*}{ SNP } & \multirow[t]{2}{*}{ Comparison } & \multirow[t]{2}{*}{ Subgroup } & \multicolumn{2}{|c|}{ Heterogeneity test } & \multirow[t]{2}{*}{ Model } & \multirow[t]{2}{*}{$\boldsymbol{P}_{Z}$} & \multirow[t]{2}{*}{$\boldsymbol{P}_{E}$} & \multirow[t]{2}{*}{ OR $(95 \%$ CI $)$} \\
\hline & & & $I^{2}(\%)$ & $\boldsymbol{P}_{H}$ & & & & \\
\hline \multirow[t]{9}{*}{ rs4464148 } & $\mathrm{CC} v s . \mathrm{TT}+\mathrm{TC}$ & Overall & 1.3 & 0.43 & $\mathrm{~F}$ & $<0.01$ & 0.13 & $1.23(1.14-1.33)$ \\
\hline & & Caucasian & 12.3 & 0.33 & $\mathrm{~F}$ & $<0.01$ & & $1.22(1.13-1.32)$ \\
\hline & & Asian & 0 & 0.71 & $\mathrm{~F}$ & 0.03 & & $1.39(1.04-1.87)$ \\
\hline & $\mathrm{CC}+\mathrm{TC} v s . \mathrm{TT}$ & Overall & 73.8 & 0.00 & $\mathrm{R}$ & 0.07 & 0.51 & $1.10(0.99-1.22)$ \\
\hline & & Caucasian & 76.8 & 0.00 & $\mathrm{R}$ & 0.16 & & $1.08(0.97-1.21)$ \\
\hline & & Asian & 0 & 0.41 & $\mathrm{~F}$ & 0.02 & & $1.36(1.05-1.75)$ \\
\hline & C vs. T & Overall & 66.2 & 0.00 & $\mathrm{R}$ & $<0.01$ & 0.36 & $1.12(1.04-1.19)$ \\
\hline & & Caucasian & 67.7 & 0.00 & $\mathrm{R}$ & 0.01 & & $1.10(1.02-1.18)$ \\
\hline & & Asian & 66 & 0.09 & $\mathrm{~F}$ & $<0.01$ & & $1.35(1.12-1.63)$ \\
\hline \multirow[t]{9}{*}{ rs4939827 } & $\mathrm{TT} v s . \mathrm{CC}+\mathrm{TC}$ & Overall & 73.3 & 0.00 & $\mathrm{R}$ & $<0.01$ & 0.89 & $1.15(1.07-1.22)$ \\
\hline & & Caucasian & 61.2 & 0.00 & $\mathrm{R}$ & $<0.01$ & & $1.19(1.12-1.26)$ \\
\hline & & Asian & 75.8 & 0.00 & $\mathrm{R}$ & 0.73 & & $1.04(0.84-1.28)$ \\
\hline & $\mathrm{TT}+\mathrm{TC} v s . \mathrm{CC}$ & Overall & 71.8 & 0.00 & $\mathrm{R}$ & $<0.01$ & 0.14 & $1.13(1.07-1.20)$ \\
\hline & & Caucasian & 71.6 & 0.00 & $\mathrm{R}$ & $<0.01$ & & $1.16(1.08-1.24)$ \\
\hline & & Asian & 74.0 & 0.00 & $\mathrm{R}$ & 0.31 & & $1.07(0.94-1.23)$ \\
\hline & T vs. C & Overall & 79.6 & 0.00 & $\mathrm{R}$ & $<0.01$ & 0.45 & $1.11(1.06-1.16)$ \\
\hline & & Caucasian & 74.7 & 0.00 & $\mathrm{R}$ & $<0.01$ & & $1.13(1.08-1.18)$ \\
\hline & & Asian & 56.9 & 0.00 & $\mathrm{R}$ & 0.33 & & $1.07(0.94-1.21)$ \\
\hline rs12952717 & $\mathrm{TT} v s . \mathrm{CC}+\mathrm{TC}$ & Overall & 13.2 & 0.31 & $\mathrm{~F}$ & $<0.01$ & 0.54 & $1.22(1.16-1.29)$ \\
\hline
\end{tabular}

(Continued) 


\begin{tabular}{|c|c|c|c|c|c|c|c|c|}
\hline \multirow[t]{2}{*}{ SNP } & \multirow[t]{2}{*}{ Comparison } & \multirow[t]{2}{*}{ Subgroup } & \multicolumn{2}{|c|}{ Heterogeneity test } & \multirow[t]{2}{*}{ Model } & \multirow[t]{2}{*}{$\boldsymbol{P}_{Z}$} & \multirow[t]{2}{*}{$\boldsymbol{P}_{E}$} & \multirow[t]{2}{*}{ OR $(95 \% \mathrm{CI})$} \\
\hline & & & $I^{2}(\%)$ & $\boldsymbol{P}_{H}$ & & & & \\
\hline & \multirow{6}{*}{$\mathrm{TT}+\mathrm{TC} v s . \mathrm{CC}$} & Caucasian & 0 & 0.87 & $\mathrm{~F}$ & $<0.01$ & & $1.25(1.18-1.32)$ \\
\hline & & Asian & 54.9 & 0.14 & $\mathrm{~F}$ & 0.02 & & $1.31(1.04-1.65)$ \\
\hline & & Overall & 51.3 & 0.02 & $\mathrm{R}$ & $<0.01$ & 0.66 & $1.15(1.08-1.23)$ \\
\hline & & Caucasian & 45.3 & 0.06 & $\mathrm{~F}$ & $<0.01$ & & $1.19(1.13-1.25)$ \\
\hline & & Asian & 0.0 & 0.54 & $\mathrm{~F}$ & 0.082 & & $1.12(0.99-1.28)$ \\
\hline & & Overall & 51.5 & 0.02 & $\mathrm{R}$ & $<0.01$ & 0.85 & $1.13(1.09-1.19)$ \\
\hline & \multirow{2}{*}{ T vs. C } & Caucasian & 29.8 & 0.17 & $\mathrm{~F}$ & $<0.01$ & & $1.16(1.12-1.20)$ \\
\hline & & Asian & 19.6 & 0.27 & $\mathrm{~F}$ & 0.02 & & $1.13(1.02-1.25)$ \\
\hline
\end{tabular}

$\boldsymbol{P}_{H}: P$ value of heterogeneity test; $\boldsymbol{P}_{Z}: P$ value of $Z$ test; $\boldsymbol{P}_{E}: P$ value of Egger's test. R: random-effects model. F: fixedeffects model

CI: $\left.1.14-1.33 ; P_{Z}<0.01 ; P_{H}=0.43\right]$, while only a slight association was found for the dominant genetic model: CC + TC vs. TT $\left(\mathrm{OR}=1.10 ; 95 \% \mathrm{CI}: 0.99-1.22 ; P_{Z}=0.51 ; P_{H}\right.$ $=0.00)$. Subgroup analysis according to ethnicity showed that rs4464148 was significantly associated with CRC risk in both Caucasian and Asian populations (Table 2).

\section{SMAD7 rs4939827 polymorphism}

Similarly, we investigated the association between the SMAD7 rs4939827 polymorphism and CRC risk. Significant associations were found for both the recessive (Figure 2): TT vs. TC $+\mathrm{CC}(\mathrm{OR}=1.15 ; 95 \% \mathrm{CI}: 1.07-1.22$; $\left.P_{Z}<0.01 ; P_{H}=0.00\right)$ and the dominant genetic models: TT + TC vs. CC $\left(\mathrm{OR}=1.13 ; 95 \% \mathrm{CI}: 1.07-1.20 ; P_{Z}<\right.$ $0.01 ; P_{H}=0.00$; Table 2). Subgroup analysis according to ethnicity showed that rs4939837 was significantly associated with CRC risk in the Caucasian population (27 studies: 36,062 cases and 43,518 controls): TT vs. TC+CC $\left(\mathrm{OR}=1.19 ; 95 \% \mathrm{CI}: 1.12-1.26 ; P_{Z}<0.01 ; P_{H}=0.00\right.$ for heterogeneity), whereas it had no association with CRC risk among Asians (9 studies: 12,607 cases and 16,349 controls): TT vs. TC+CC (OR $=1.04$; 95\% CI: 0.84-1.28; $P_{Z}=0.73 ; P_{H}=0.00$; Table 2).

\section{SMAD7 rs12953717 polymorphism}

In this meta-analysis, a strong association between the rs12953717 polymorphism and CRC risk was found for both the recessive: TT vs. CC+TC $(\mathrm{OR}=1.22 ; 95 \%$ CI: $\left.1.16-1.29 ; P_{Z}<0.01 ; P_{H}=0.31\right)$ and the dominant genetic models: TT+TC vs. CC $(\mathrm{OR}=1.15$; $95 \% \mathrm{CI}: 1.08$ 1.23; $P_{Z}<0.01 ; P_{H}=0.02$; Table 2). Further subgroup analysis based on ethnicity showed that rs12953717 was significantly associated with the risk of CRC in both Caucasians and Asians (Table 2).

\section{Sensitivity analyses and publication bias}

Our results suggested that the influence of individual data sets to the pooled ORs were not significant. Sensitivity analysis showed that no single study qualitatively altered the pooled ORs, providing evidence of the stability of the meta-analysis (Supplementary Figure S1). Funnel plots and Egger's test were performed to assess publication bias. The results suggested that there was no publication bias for the comparison of rs 4464148 allele $\mathrm{C}$ vs. allele $\mathrm{T}\left(t=0.96, P_{E}=\right.$ $0.36)$, rs4939827 allele T vs. allele $\mathrm{C}\left(t=-0.76, P_{E}=0.45\right)$, or rs 12953717 allele T vs. allele $\mathrm{C}\left(t=-0.19, P_{E}=0.85\right)$. The shape of Begg's funnel plot did not reveal any obvious asymmetry (Supplementary Figure S2).

\section{DISCUSSION}

TGF- $\beta$ signaling is essential for maintaining homeostasis, cell differentiation, and tumor suppression $[3,24,25]$. Increased production of TGF- $\beta$ occurs in various tumor types, such as CRC [26]. As one of the key effectors of TGF- $\beta$ signaling, perturbation of SMAD7 expression has been documented to influence CRC progression [7][27]. Though the functional role of the SMAD7 polymorphisms (rs4464148, rs4939827, and rs12953717) has not yet been interpreted, a number of published epidemiological studies have reported that these polymorphisms are correlated with the risk of developing multiple cancers [12, 28, 29]. However, other studies have reported that these polymorphisms are not associated with cancer development [17-20].

These conflicting studies based their conclusions on small numbers of samples and different detection methods. Therefore ameta-analysis from large-scale samples of all available studies is required to have a more accurate assessment as to whether the SMAD7 polymorphisms are related to risk of developing CRC. Our group has already used meta-analysis to systematically investigate the association between cancer risk and several SNPs involved in TGF- $\beta$ signaling [30-32]. In this metaanalysis, we found SMAD7 polymorphisms (rs4464148, rs4939827, and rs12953717) in the combined population were all significantly associated with CRC risk. Subgroup analysis according to ethnicity showed that rs4464148 
and rs12953717 were significantly associated with the risk of CRC among both Caucasian and Asian population, whereas rs4939827 seems to be a risk polymorphism for CRC only within a Caucasian population. There could be several possibilities to explain such a differential association. First, the difference in association may result from differences in socioeconomic environment, regional dietary habits, and race. Second, the number of rs4939827 in Asian studies is still not as large as desired. In addition, the results from nine studies incorporated in this metaanalysis conflict with each other [14, 19, 22, 33-38]. Therefore, more Asian studies are still needed to clearly evaluate the interactions of SMAD7 rs4939827 and CRC in this ethnic group.

One recent study [39] also assessed the associations between these three SNPs and CRC risk by meta-analysis; however, there were significant limitations. First, the number of studies included in their analysis was smaller than ours. Only 4 publications for rs4464148, which also lack relevant studies for Asian population, and 13

A

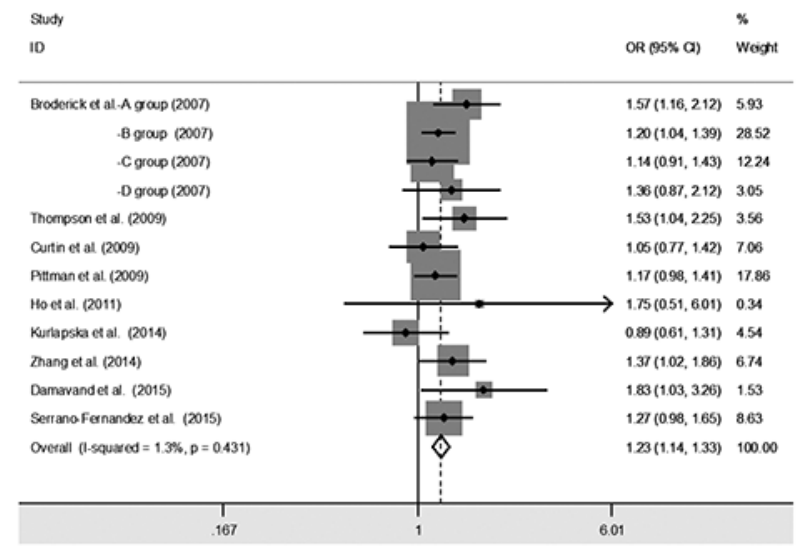

C

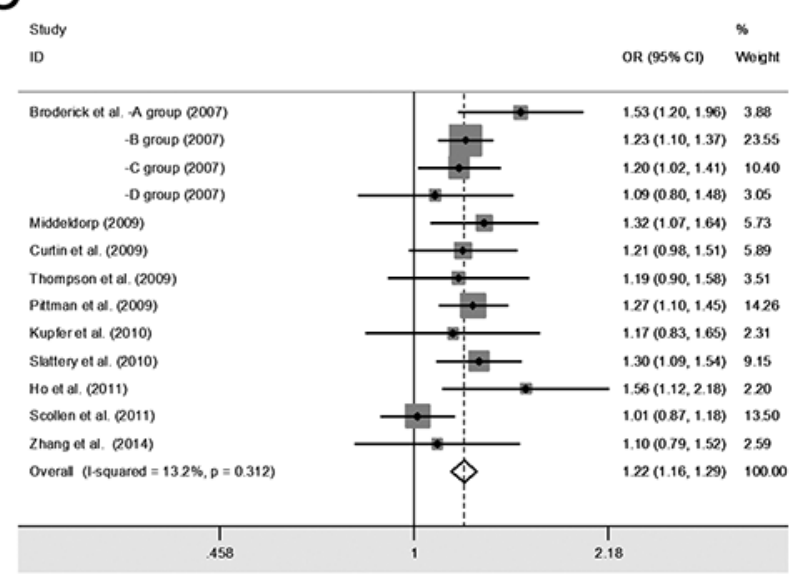

publications for rs4939827 were included in their metaanalysis, while 9 publications for rs4464148 and 25 publications for rs4939827 were included in our work. Second, they only analyzed the relationship between SMAD7 polymorphisms and CRC risk under an allelic model, while we also analyzed under dominant and recessive models. Therefore, our updated meta-analysis at a much larger scale clearly provides a more credible and reliable assessment for the association between SMAD7 polymorphisms and the risk to develop CRC.

Nonetheless, we also wish to acknowledge the limitations in our study. First, we stratified the studies by ethnic subtypes as Caucasian and Asian. However, we could not assess the association in the African population due to the insufficient number of African studies. Second, further subtle adjusted analysis could be carried out if more detailed individual information was available. Third, we only assessed the association of SMAD7 polymorphisms with $\mathrm{CRC}$ risk, because there were not sufficient studies conducted on other cancers.

B

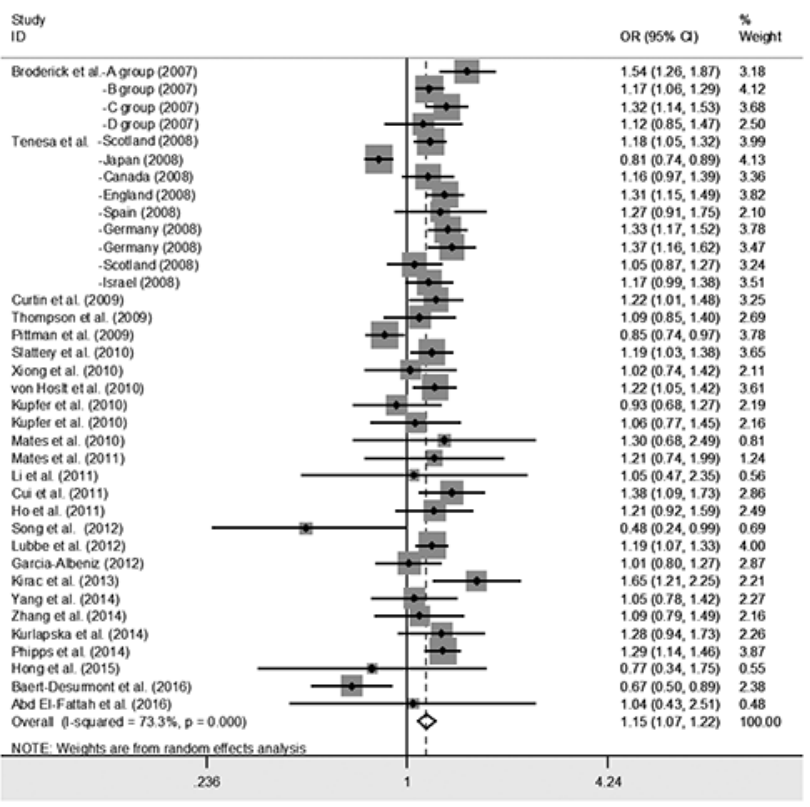

Figure 2: Forest plot of cancer risk associated with the $S M A D 7$ polymorphisms in colorectal cancer studies with recessive genetic models. The squares and horizontal lines correspond to the study-specific odds ratio (OR) and 95\% confidence interval $(95 \% \mathrm{CI})$. The area of the squares reflects the weight (inverse of the variance). A. SMAD7 rs4464148; B. SMAD7 rs4939827; C. SMAD7 rs12953717. 
To date, a large number of studies have focused on the relationship between $S M A D 7$ polymorphisms and cancer. However, controversies remain as whether those polymorphisms indeed associate with increased cancer risks. Our large-scale meta-analysis demonstrated that the C allele of rs4464148, the T allele of rs4939827, and the $\mathrm{T}$ allele of rs12953717 were all significantly associated with the increased CRC risk, which may provide a basis for genetic testing in the development of CRC. Consistent with our findings, Noci et al. [40] recently showed that SMAD7 rs4939827 is also associated with cancer survival rate after therapy. Therefore, the identification of SMAD7 polymorphisms may also benefit developing targeted and personalized therapy against CRC. However, more comparative studies are needed to evaluate interactions of $S M A D 7$ polymorphisms and cancer risk in other specific cancer subtypes and ethnic subtypes

\section{MATERIALS AND METHODS}

\section{Literature Search strategy}

We searched for relevant case-control studies using the following words and terms: "SMAD7", "Mothers against decapentaplegic homolog 7", "rs4464148", “rs4939827”, “rs12953717”, “polymorphism” or "variation", "susceptibility", and "tumor" or "cancer" or "carcinoma" or "neoplasia" or "colorectal caner" or "CRC" in PubMed, the Web of Science, EBSCO, and Embase databases. There were no limitations on the language and year for the literature search. The last search was updated on June 30, 2016. References of the retrieved publications were also screened.

\section{Inclusion criteria}

Two authors independently screened titles and abstracts to identify relevant studies. Full-text articles of these studies were then carefully read to select eligible studies. Studies had to meet the following inclusion criteria: (a) were a case-control study, nested case-control or a cohort study; (b) evaluated the association between SMAD7 polymorphisms ("rs4464148", "rs4939827", and "rs12953717") and CRC risk; (c) had available genotype frequencies both in cases and controls; (d) the genotype distribution in control groups was in Hardy-Weinberg equilibrium (HWE). (e) In cases of multiple studies with overlapping, redundant data published, only the most recent or complete study was included.

\section{Qualitative assessment}

Two authors independently conducted the quality assessment. The Newcastle-Ottawa Scale (NOS) was used to evaluate the study quality, which scored studies by the selection of the groups, the comparability of cases and controls, and the ascertainment of the exposure. We considered a study awarded 0-3, 4-6, or 7-9 as a low-, moderate-, or high-quality study, respectively [23].

\section{Data extraction}

Two authors independently selected the relevant articles and extracted the following data: first author's name, publication date, ethnicity, cancer type, genotyping methods, number of cases and controls, and number of genotypes in case-control groups. In addition, $P$ values according to the HWE in controls were extracted from the included studies.

\section{Statistical analysis}

Our meta-analysis was performed using Stata software (version 12.0; StataCorp LP, College Station, TX, USA). We first calculated the strength of the association between SMAD7 polymorphisms and CRC by odds ratio (OR) corresponding to $95 \%$ confidence interval (CI) for different genetic models. Then we stratified the studies by ethnic subtypes and examined the association between SMAD7 polymorphisms and the CRC risk (Table 2). A chi-square-based $Q$-statistic test [41] was performed to evaluate the between-study heterogeneity of the studies. $P_{H}<0.05$ was considered significant for heterogeneity. We also calculated the quantity $I^{2}$ that represents the percentage of total variation across studies. As a guide, values of $I^{2}$ less than $25 \%$ were considered "low", values about $50 \%$ were considered "moderate", and values greater than $75 \%$ were considered "high"[42]. The fixed effects model was used when there was no heterogeneity of the results of studies; otherwise, the random-effects model was chosen. A pooled OR obtained by meta-analysis was used to give a more reasonable evaluation of the association. The significance of the pooled OR was determined by $Z$ test $\left(P_{Z} \leq 0.05\right.$ suggests a significant $\left.\mathrm{OR}\right)$. Funnel plots were used to access publication bias by the method of Begg's test and Egger's test. A T test was performed to determine the significance of the asymmetry. An asymmetric plot suggested possible publication bias $\left(P_{E} \geq 0.05\right.$ suggests no bias).

\section{ACKNOWLEDGMENTS}

This study was supported by grants from the National Natural Science Foundation of China (Grant No. 31201050 and 81372201).

\section{CONFLICTS OF INTEREST}

The authors declare no competing financial interests. 


\section{REFERENCES}

1. Pharoah PD, Dunning AM, Ponder BA, Easton DF. Association studies for finding cancer-susceptibility genetic variants. Nat Rev Cancer. 2004; 4: 850-60. doi: 10.1038/ nrc1476.

2. Massague J. TGFbeta in Cancer. Cell. 2008; 134: 215-30. doi: 10.1016/j.cell.2008.07.001.

3. Li Z, Zhang LJ, Zhang HR, Tian GF, Tian J, Mao XL, Jia ZH, Meng ZY, Zhao LQ, Yin ZN, Wu ZZ. Tumor-Derived Transforming Growth Factor-beta is Critical for Tumor Progression and Evasion from Immune Surveillance. Asian Pac J Cancer Prev. 2014; 15: 5181-6.

4. Ikushima H, Miyazono K. TGFbeta signalling: a complex web in cancer progression. Nat Rev Cancer. 2010; 10: 41524. doi: $10.1038 / \mathrm{nrc} 2853$.

5. Schmierer B, Hill CS. TGFbeta-SMAD signal transduction: molecular specificity and functional flexibility. Nat Rev Mol Cell Biol. 2007; 8: 970-82. doi: 10.1038/nrm2297.

6. Hayashi H, Abdollah S, Qiu Y, Cai J, Xu YY, Grinnell BW, Richardson MA, Topper JN, Gimbrone MA, Jr., Wrana JL, Falb D. The MAD-related protein Smad7 associates with the TGFbeta receptor and functions as an antagonist of TGFbeta signaling. Cell. 1997; 89: 1165-73.

7. Grau AM, Datta PK, Zi J, Halder SK, Beauchamp RD. Role of Smad proteins in the regulation of NF-kappaB by TGFbeta in colon cancer cells. Cell Signal. 2006; 18: 1041-50. doi: 10.1016/j.cellsig.2005.08.021

8. Azuma H, Ehata S, Miyazaki H, Watabe T, Maruyama O, Imamura T, Sakamoto T, Kiyama S, Kiyama Y, Ubai T, Inamoto T, Takahara S, Itoh Y, et al. Effect of Smad7 expression on metastasis of mouse mammary carcinoma JygMC(A) cells. J Natl Cancer Inst. 2005; 97: 1734-46. doi: 10.1093/jnci/dji399.

9. Mikula M, Proell V, Fischer AN, Mikulits W. Activated hepatic stellate cells induce tumor progression of neoplastic hepatocytes in a TGF-beta dependent fashion. J Cell Physiol. 2006; 209: 560-7. doi: 10.1002/jcp.20772.

10. Akel S, Bertolette D, Petrow-Sadowski C, Ruscetti FW. Levels of Smad7 regulate Smad and mitogen activated kinases (MAPKs) signaling and controls erythroid and megakaryocytic differentiation of erythroleukemia cells. Platelets. 2007; 18: 566-78. doi: 10.1080/09537100701549546.

11. Iwai T, Murai J, Yoshikawa H, Tsumaki N. Smad7 Inhibits chondrocyte differentiation at multiple steps during endochondral bone formation and down-regulates p38 MAPK pathways. J Biol Chem. 2008; 283: 27154-64. doi: 10.1074/jbc.M801175200.

12. Broderick P, Carvajal-Carmona L, Pittman AM, Webb E, Howarth K, Rowan A, Lubbe S, Spain S, Sullivan K, Fielding S, Jaeger E, Vijayakrishnan J, Kemp Z, et al. A genome-wide association study shows that common alleles of SMAD7 influence colorectal cancer risk. Nat Genet. 2007; 39: 1315-7. doi: 10.1038/ng.2007.18.

13. Middeldorp A, Jagmohan-Changur S, van Eijk R, Tops C, Devilee P, Vasen HF, Hes FJ, Houlston R, Tomlinson I, Houwing-Duistermaat JJ, Wijnen JT, Morreau H, van Wezel T. Enrichment of low penetrance susceptibility loci in a Dutch familial colorectal cancer cohort. Cancer Epidemiol Biomarkers Prev. 2009; 18: 3062-7. doi: 10.1158/10559965.EPI-09-0601.

14. Tenesa A, Farrington SM, Prendergast JG, Porteous ME, Walker M, Haq N, Barnetson RA, Theodoratou E, Cetnarskyj R, Cartwright N, Semple C, Clark AJ, Reid FJ, et al. Genome-wide association scan identifies a colorectal cancer susceptibility locus on 11q23 and replicates risk loci at 8q24 and 18q21. Nat Genet. 2008; 40: 631-7. doi: 10.1038/ng.133.

15. Hirata H, Hinoda Y, Nakajima K, Kikuno N, Yamamura S, Kawakami K, Suehiro Y, Tabatabai ZL, Ishii N, Dahiya $\mathrm{R}$. Wnt antagonist gene polymorphisms and renal cancer. Cancer. 2009; 115: 4488-503. doi: 10.1002/cncr.24491.

16. Ji J, Xu M, Zhao Z, Tu J, Gao J, Lu C, Song J, Chen W, Chen M, Fan X, Cheng X, Lan X, Li J. SMAD7 loci contribute to risk of hepatocellular carcinoma and clinicopathologic development among Chinese Han population. Oncotarget. 2016; 7:22186-92. doi: 10.18632/oncotarget.8065.

17. Kurlapska A, Serrano-Fernandez P, Baszuk P, Gupta S, Starzynska T, Malecka-Panas E, Dabrowski A, Debniak T, Kurzawski G, Suchy J, Rogoza-Mateja W, Scott RJ, Lubinski J. Cumulative effects of genetic markers and the detection of advanced colorectal neoplasias by population screening. Clin Genet. 2014. doi: 10.1111/cge.12481.

18. Abd El-Fattah AA, Sadik NA, Shaker OG, Kamal AM. Are SMAD7 rs4939827 and CHI3L1 rs4950928 polymorphisms associated with colorectal cancer in Egyptian patients? Tumour Biol. 2016. doi: 10.1007/s13277-016-4813-8.

19. Hong SN, Park C, Kim JI, Kim DH, Kim HC, Chang DK, Rhee PL, Kim JJ, Rhee JC, Son HJ, Kim YH. Colorectal cancer-susceptibility single-nucleotide polymorphisms in Korean population. J Gastroenterol Hepatol. 2015; 30: 84957. doi: 10.1111/jgh.12331.

20. Gibson L, Johnson N, Fraser A, dos Santos Silva I, Houlston R, Peto J, Fletcher O. No breast cancer association for transforming growth factor-beta pathway colorectal cancer single nucleotide polymorphisms. Cancer Epidemiol Biomarkers Prev. 2009; 18: 1934-6. doi: 10.1158/10559965.EPI-09-0214.

21. Broderick P, Sellick G, Fielding S, Catovsky D, Houlston R. Lack of a relationship between the common 18q24 variant rs12953717 and risk of chronic lymphocytic leukemia. Leuk Lymphoma. 2008; 49: 271-2. doi: 10.1080/10428190701817290.

22. Li X, Yang XX, Hu NY, Sun JZ, Li FX, Li M. A riskassociated single nucleotide polymorphism of SMAD7 is common to colorectal, gastric, and lung cancers in a Han 
Chinese population. Mol Biol Rep. 2011; 38: 5093-7. doi: 10.1007/s11033-010-0656-3.

23. Wells GA, Shea B, O'Connell D, Peterson J, Welch V, Losos M, Tugwell P. The Newcastle-Ottawa Scale (NOS) for assessing the quality of nonrandomised studies in meta-analyses.

24. Wu MY, Hill CS. Tgf-beta superfamily signaling in embryonic development and homeostasis. Dev Cell. 2009; 16: 329-43. doi: 10.1016/j.devcel.2009.02.012.

25. Massague J. TGFbeta signalling in context. Nat Rev Mol Cell Biol. 2012; 13: 616-30. doi: 10.1038/nrm3434.

26. $\mathrm{Xu} \mathrm{Y,} \mathrm{Pasche} \mathrm{B.} \mathrm{TGF-beta} \mathrm{signaling} \mathrm{alterations} \mathrm{and}$ susceptibility to colorectal cancer. Hum Mol Genet. 2007; 16 Spec No 1: R14-20. doi: 10.1093/hmg/ddl486.

27. Halder SK, Rachakonda G, Deane NG, Datta PK. Smad7 induces hepatic metastasis in colorectal cancer. Br J Cancer. 2008; 99: 957-65. doi: 10.1038/sj.bjc.6604562.

28. Thompson CL, Plummer SJ, Acheson LS, Tucker TC, Casey G, Li L. Association of common genetic variants in SMAD7 and risk of colon cancer. Carcinogenesis. 2009; 30: 982-6. doi: 10.1093/carcin/bgp086.

29. Damavand B, Derakhshani S, Saeedi N, Mohebbi SR, Milanizadeh S, Azimzadeh P, Aghdaie HA, Zali MR. Intronic polymorphisms of the SMAD7 gene in association with colorectal cancer. Asian Pac J Cancer Prev. 2015; 16: 41-4.

30. Huang Y, Hao Y, Li B, Xie J, Qian J, Chao C, Yu L. Lack of significant association between TGF-beta1-590C/T polymorphism and breast cancer risk: a meta-analysis. Med Oncol. 2011; 28: 424-8. doi: 10.1007/s12032-010-9491-6.

31. Huang Y, Li B, Qian J, Xie J, Yu L. TGF-beta1 29T/C polymorphism and breast cancer risk: a meta-analysis involving 25,996 subjects. Breast Cancer Res Treat. 2010; 123: 863-8. doi: 10.1007/s10549-010-0796-0.

32. Huang YS, Zhong Y, Yu L, Wang L. Association between the TGFBR2 G-875A polymorphism and cancer risk: evidence from a meta-analysis. Asian Pac J Cancer Prev. 2014; 15: 8705-8.

33. Xiong F, Wu C, Bi X, Yu D, Huang L, Xu J, Zhang T, Zhai K, Chang J, Tan W, Cai J, Lin D. Risk of genome-wide association study-identified genetic variants for colorectal cancer in a Chinese population. Cancer Epidemiol Biomarkers Prev. 2010; 19: 1855-61. doi: 10.1158/10559965.EPI-10-0210.

34. Cui R, Okada Y, Jang SG, Ku JL, Park JG, Kamatani Y, Hosono N, Tsunoda T, Kumar V, Tanikawa C, Kamatani N, Yamada R, Kubo M, et al. Common variant in 6q26-q27 is associated with distal colon cancer in an Asian population. Gut. 2011; 60: 799-805. doi: 10.1136/gut.2010.215947.

35. Ho JW, Choi SC, Lee YF, Hui TC, Cherny SS, GarciaBarcelo MM, Carvajal-Carmona L, Liu R, To SH, Yau TK, Chung CC, Yau CC, Hui SM, et al. Replication study of SNP associations for colorectal cancer in Hong Kong
Chinese. Br J Cancer. 2011; 104: 369-75. doi: 10.1038/ sj.bjc. 6605977.

36. Song Q, Zhu B, Hu W, Cheng L, Gong H, Xu B, Zheng X, Zou L, Zhong R, Duan S, Chen W, Rui R, Wu J, et al. A common SMAD7 variant is associated with risk of colorectal cancer: evidence from a case-control study and a meta-analysis. PLoS One. 2012; 7: e33318. doi: 10.1371/ journal.pone.0033318.

37. Yang CY, Lu RH, Lin CH, Jen CH, Tung CY, Yang SH, Lin JK, Jiang JK, Lin CH. Single nucleotide polymorphisms associated with colorectal cancer susceptibility and loss of heterozygosity in a Taiwanese population. PLoS One. 2014; 9: e100060. doi: 10.1371/journal.pone.0100060.

38. Zhang B, Jia WH, Matsuo K, Shin A, Xiang YB, Matsuda K, Jee SH, Kim DH, Cheah PY, Ren Z, Cai Q, Long J, Shi $\mathrm{J}$, et al. Genome-wide association study identifies a new SMAD7 risk variant associated with colorectal cancer risk in East Asians. Int J Cancer. 2014; 135: 948-55. doi: 10.1002/ijc. 28733.

39. Yao K, Hua L, Wei L, Meng J, Hu J. Correlation Between CASC8, SMAD7 Polymorphisms and the Susceptibility to Colorectal Cancer: An Updated Meta-Analysis Based on GWAS Results. Medicine (Baltimore). 2015; 94: e1884. doi: 10.1097/MD.0000000000001884.

40. Noci S, Dugo M, Bertola F, Melotti F, Vannelli A, Dragani TA, Galvan A. A subset of genetic susceptibility variants for colorectal cancer also has prognostic value. Pharmacogenomics J. 2016; 16: 173-9. doi: 10.1038/ tpj.2015.35.

41. Handoll HH. Systematic reviews on rehabilitation interventions. Arch Phys Med Rehabil. 2006; 87: 875. doi: 10.1016/j.apmr.2006.04.006.

42. Higgins JP, Thompson SG, Deeks JJ, Altman DG. Measuring inconsistency in meta-analyses. BMJ. 2003; 327 : 557-60. doi: 10.1136/bmj.327.7414.557.

43. Curtin K, Lin WY, George R, Katory M, Shorto J, CannonAlbright LA, Bishop DT, Cox A, Camp NJ, Colorectal Cancer Study G. Meta association of colorectal cancer confirms risk alleles at 8q24 and 18q21. Cancer Epidemiol Biomarkers Prev. 2009; 18: 616-21. doi: 10.1158/10559965.EPI-08-0690.

44. Pittman AM, Naranjo S, Webb E, Broderick P, Lips EH, van Wezel T, Morreau H, Sullivan K, Fielding S, Twiss P, Vijayakrishnan J, Casares F, Qureshi M, et al. The colorectal cancer risk at $18 \mathrm{q} 21$ is caused by a novel variant altering SMAD7 expression. Genome Res. 2009; 19: 987-93. doi: 10.1101/gr.092668.109.

45. Serrano-Fernandez P, Dymerska D, Kurzawski G, Derkacz R, Sobieszczanska T, Banaszkiewicz Z, Roomere H, Oitmaa E, Metspalu A, Janavicius R, Elsakov P, Razumas M, Petrulis K, et al. Cumulative Small Effect Genetic Markers and the Risk of Colorectal Cancer in Poland, Estonia, Lithuania, and Latvia. Gastroenterol Res Pract. 2015; 2015: 204089. doi: 10.1155/2015/204089. 
46. Slattery ML, Herrick J, Curtin K, Samowitz W, Wolff RK, Caan BJ, Duggan D, Potter JD, Peters U. Increased risk of colon cancer associated with a genetic polymorphism of SMAD7. Cancer Res. 2010; 70: 1479-85. doi: 10.1158/0008-5472.CAN-08-1792.

47. von Holst S, Picelli S, Edler D, Lenander C, Dalen J, Hjern F, Lundqvist N, Lindforss U, Pahlman L, Smedh K, Tornqvist A, Holm J, Janson M, et al. Association studies on 11 published colorectal cancer risk loci. Br J Cancer. 2010; 103: 575-80. doi: 10.1038/sj.bjc.6605774.

48. Kupfer SS, Anderson JR, Hooker S, Skol A, Kittles RA, Keku TO, Sandler RS, Ellis NA. Genetic heterogeneity in colorectal cancer associations between African and European americans. Gastroenterology. 2010; 139: 1677 85, 85 e1-8. doi: 10.1053/j.gastro.2010.07.038.

49. Mates IN, Csiki I, Mates D, Constantinescu V, Badea P, Dinu D, Constantin A, Constantinoiu S. Association of common genetic variants with colorectal cancer risk in a Romanian sample. Chirurgia (Bucur). 2010; 105: 749-57.

50. Mates IN, Jinga V, Csiki IE, Mates D, Dinu D, Constantin A, Jinga M. Single nucleotide polymorphisms in colorectal cancer: associations with tumor site and TNM stage. J Gastrointestin Liver Dis. 2012; 21: 45-52.

51. Lubbe SJ, Whiffin N, Chandler I, Broderick P, Houlston RS. Relationship between 16 susceptibility loci and colorectal cancer phenotype in 3146 patients. Carcinogenesis. 2012; 33: 108-12. doi: 10.1093/carcin/bgr243.

52. Garcia-Albeniz X, Nan H, Valeri L, Morikawa T, Kuchiba A, Phipps AI, Hutter CM, Peters U, Newcomb PA, Fuchs
CS, Giovannucci EL, Ogino S, Chan AT. Phenotypic and tumor molecular characterization of colorectal cancer in relation to a susceptibility SMAD7 variant associated with survival. Carcinogenesis. 2013; 34: 292-8. doi: 10.1093/ carcin/bgs335.

53. Phipps AI, Newcomb PA, Garcia-Albeniz X, Hutter CM, White E, Fuchs CS, Hazra A, Ogino S, Nan H, Ma J, Campbell PT, Figueiredo JC, Peters U, et al. Association between colorectal cancer susceptibility loci and survival time after diagnosis with colorectal cancer. Gastroenterology. 2012; 143: 51-4 e4. doi: 10.1053/j. gastro.2012.04.052.

54. Kirac I, Matosevic P, Augustin G, Simunovic I, Hostic V, Zupancic S, Hayward C, Antoljak N, Rudan I, Campbell H, Dunlop MG, Velimir Vrdoljak D, Kovacevic D, et al. SMAD7 variant rs4939827 is associated with colorectal cancer risk in Croatian population. PLoS One. 2013; 8: e74042. doi: 10.1371/journal.pone.0074042.

55. Baert-Desurmont S, Charbonnier F, Houivet E, Ippolito L, Mauillon J, Bougeard M, Abadie C, Malka D, Duffour J, Desseigne F, Colas C, Pujol P, Lejeune S, et al. Clinical relevance of $8 \mathrm{q} 23,15 \mathrm{q} 13$ and $18 \mathrm{q} 21$ SNP genotyping to evaluate colorectal cancer risk. Eur J Hum Genet. 2016; 24 : 99-105. doi: 10.1038/ejhg.2015.72.

56. Scollen S, Luccarini C, Baynes C, Driver K, Humphreys MK, Garcia-Closas M, Figueroa J, Lissowska J, Pharoah PD, Easton DF, Hesketh R, Metcalfe JC, Dunning AM. TGF-beta signaling pathway and breast cancer susceptibility. Cancer Epidemiol Biomarkers Prev. 2011; 20: 1112-9. doi: 10.1158/1055-9965.EPI-11-0062. 